https://helda.helsinki.fi

\title{
Promoting Value Practice in Museums Creates Impact
}

\author{
Robbins, Nina
}

2020-01

Robbins, N 2020 , ' Promoting Value Practice in Museums Creates Impact ' , Curator, vol. 63 , no. 1 , pp. 55-68 . https://doi.org/10.1111/cura.12350

http://hdl.handle.net/10138/337991

https://doi.org/10.1111/cura.12350

acceptedVersion

Downloaded from Helda, University of Helsinki institutional repository.

This is an electronic reprint of the original article.

This reprint may differ from the original in pagination and typographic detail.

Please cite the original version. 


\section{Promoting Value Practice in Museums Creates Impact}

NINA ROBBINS

Abstract This article examines how museological value discussion can offer a tool for museum professionals to engage themselves in the current discourse regarding building sustainable futures. The focus of the article is on collection care and collection development. It describes the latest interview and workshop results regarding museum values in the field of collection development among Finnish museum professionals and students. In addition, it emphasizes the integration of theoretical knowledge and its practical application. Promoting and creating opportunities for value discussion among museum professionals increases the ability of these professionals to further engage in such value-related discourse with various stakeholders. Eventually, the benefits of this kind of value-based discussions are to be seen in the more coherent and focused ones regarding museological values between and among various parties, be they museum professionals, politicians, students or museum visitors. The initial idea for the interviews, and subsequently the workshops as well, emerged from a collection development survey conducted in 2012 among Finnish art museums, which was published in 2016 by the author. Based on the material analyzed at that time, it became clear that the issue of active values in Finnish museums would need further study.

\section{INTRODUCTION}

It is clear that value-based discussion within any institution is an ongoing process. As part of the professional conduct every new gen- eration needs to situate themselves in the con- text of these discussions. In order to get information about the current value discourse taking place in Finnish museums and among Finnish students, as well as to further enrich the value material previously gathered from the col- lection development survey conducted in 2016, hands-on value workshops for students and a set of peer-to-peer interviews for museum profes- sionals were planned. These took place in 2017 and 2018.

In spring 2018, I interviewed four museum professionals about the direction of collection development in Finland: the Collection Curator from the Tuusula Art Museum, located in a rural area in southern Finland; the Collection Man- agement Director from the National Gallery of Finland, located in Helsinki; the Collection Curator from the Rovaniemi Art Museum, located in southern Lapland and the Collection Curator from the Helsinki City Museum, located in Helsinki. In addition to the museum inter- views, four hands-on value workshops for students were organized in 2017 and 2018 in the following educational institutions: bachelor- and master's-level students of the Helsinki University Museum Studies program, master's-level

Nina Robbins (nina.robbins@helsinki.fi) is a university lecturer at the University of Helsinki where she teaches MA-level museology. She received her doctorate in 2016, her subject being disposals in Finnish art museums. She also holds a higher degree (YAMK) in art conservation. During her career as curator of collections, conserva- tor and university lecturer she has developed a wide perspective in the field of cultural heritage. She places great importance in passing on to her university students not only theoretical knowledge, but also its corre- sponding practical knowledge. She feels that the field of museology offers an enduring bridge between the vari- ous fields of heritage management. Beneficially integrating the forces from these different fields will become ever more important in a world where financial resources are increasingly scrutinized.

(C) 2019 Wiley Periodicals, Inc. 1

\section{CURATOR: THE MUSEUM JOURNAL}

students of the Reinwardt Academy Museum Studies program, located in Amsterdam and bachelor-level students of conservation from the Metropolia Polytechnic in Helsinki. These two- hour workshops were part of an ongoing process, working towards the aim of increasing hands-on and value-related practices among future museum professionals (Thomas, Wessman and Heikkil€a 2018). This is why the article focuses on the professional application of values, rather than on their philosophical traditions and aspects.

In the article, the term "value" is understood to encompass cultural, aesthetic and moral guidelines, under which museum professionals conduct their preservation work in museums (ICOM Strategic Plan 2016-2022, 2018). These guidelines have their origin in such disci- plines as history and philosophy but need practi- cal application in order to function as tools for museum professionals. For its part, the study continues the endeavor towards such approaches in the field of museology, creating tools for museum professionals to engage in value-ori- ented discussions. The aim is eventually to inspire future students of museology and future museum professionals to actively engage and challenge themselves in these discussions. Prior research shows that in order for value discussions to result in applicable, real-life tools, it is impor- tant to achieve a coherent understanding of the value network behind any given actions (Holden 2006; Scott 2013). This means making the val- ues that guide 
our work visible and reveal the impact factor of that work. The results of this research is offering tools toward this end.

\section{MUSEOLOGICAL VALUE DISCUSSION AND PRACTICAL APPLICATION OF VALUES}

It is clear that our world values various phe- nomena from multiple perspectives:

philosophical, aesthetic, morally bound, ethical and economic. In general, values are an essential part of any museum practice, and give the needed support for decision-making. Economic pressures have challenged museums to focus on their message and significance. In this work, one cannot find relevant outcomes without value discussions, and values are generally seen more from a practical point of view than through their philosophical interpretations, i.e. efforts are made to come up with practical appli- cations to ease the everyday work of profession- als. The philosophical tradition offers the needed background for this work and functions as the base camp on which to build any profes- sional applications (Danto 1964; Dickie 1971; 1974; 2001; Wollheim 1980; Haapala 2010). Within the museum profession it is especially in the field of value application that values have been studied (Holden 2006; Ehdotus museopoliittiseksi ohjelmaksi 2017; Piekkola, Suojanen and Vaino 2013; Porter and Kramer 2011; Scott 2008; Scott 2013). In addition to the traditional philosophical or aesthetic approaches to values, these studies show how to evaluate real-life situations and how to help expedite the application of practical tools. They take the contemporary environment as their starting point, relying largely on the current audience experience when analyzing the various values that effect museum work. Since the turn of the new millennium there has been a growing interest in studying non-profit organizations, especially the meaningfulness of museums, as well as to map out those audiences to whom museums might matter (Weil 2002; Knell 2004; Simon 2010). All this indicates that museums can be policy makers in the field of cultural her- itage. In general, authors introduce methods of making museum work relevant to various audi- ences. The need for a wide perspective is acknowledged in these studies, but the emphasis

2

Article: Promoting Value Practice in Museums Creates Impact

is often on the meaningfulness of our own time or the meaningfulness of current visitor experi- ences. Such terms as "audience engagement" and "co-creation" are used to describe current trends in museological writing. Furthermore, more extreme themes such as "Do museums still need objects?" (Conn 2010) or "Reinventing the museum" (Anderson 2004) have been intro- duced. There are suggestions to use the collec- tions more effectively and requests to act like les enfants terribles (Museums 2020 2012: 19-20).

Currently, meaningfulness is rarely seen from the collection care and development per- spective or as a potentially long-term and accu- mulative feature. This became clear also from the Artefacta (The Finnish Network for Arte- fact Studies) survey results of Konkreettinen esinetutkimus harvinaista (Concrete Object Research is Rare) published in 2016. Artefacta is an open network of researchers, museum pro- fessionals, students and people interested in our cultural heritage. It promotes object research and aims to increase the appreciation of material culture in Finland. In their 2016 survey, they mapped out the level of object research and ascertained reasons for the low level of interest. The survey was directed towards all who had conducted object research during their careers, as well as towards collection caretakers in muse- ums. Of the survey answers, 89\% thought that the level of object research was low. The survey listed various reasons for this: research about our material culture is not fashionable today, a fundamental lack of resources, a lack of personnel or time and the inevitably covert character of object research were among the reasons listed in the survey answers. Furthermore, it was indi- cated that interest in general has shifted towards other issues and themes in memory organiza- tions, and various short-term functions were especially seen as resource consuming. Different digital applications were also considered.

Digital platforms such as www.finna.fi (a free access search service for Finnish museums, libraries and archives) were seen as helpful in making preliminary mapping of material, but not as information rich enough to function as serious research tools. Survey answers added that co-operation between universities and museums should be further nurtured, and per- sonnel exchange between universities and museums should be developed. It was seen as important that museum collections open them- selves up more to researchers and any research results would be freely available to museums. The idea of open access was promoted (Arte- facta 2016). Methods suggested in the Artefacta survey have not gone unnoticed. Focusing on the practical application of museum value work will 
result into finding co-operative projects between researchers and museum professionals. This will eventually create a common ground for understanding.

There are statements, surveys and collec- tion-oriented writings that recognize objects' cumulative meaningfulness and their interpre- tative potential. In contemporary museological literature these efforts are often referred to with terms such as "making museums matter" (Weil 2002), "analyzing significance" and "writing of significance statements" (Russell and Wink- worth 2009; Assessing Museum Collections in Six Steps 2014; H€ayh€a et al., 2015), "pointing out cultural biographies" (Van Mensch and Meijer- van Mensch 2011) or "selecting the key objects" (Lehto-Vahtera 2018). Focusing on such themes as significance has become a useful tool for defining legitimacy in the field of cultural heritage at a time when financial resources are being scrutinized. The Finnish significance evaluation, Analyzing Significance (2015) is a tool designed for Finnish museum collections to determine the level of collection objects' signifi- cance and museum value. It is based on its

Nina Robbins

CURATOR: THE MUSEUM JOURNAL

international counterparts, such as the Aus- tralian Significance 2.0 (2009) or Dutch Assessing Museum Collections in Six Steps (2014). The method is designed to work together with other means of documentation and value assessment used in museums and to produce a significance statement as a result. It is a method to enrich the information contained in museum collections. Furthermore, in the field of conservation, values are tested in practice during any given conserva- tion project. A conservator has to be aware of the existing value network of the project at hand, in order to conduct sound conservation procedures (Appelbaum 2007).

The idea of analyzing significance is not necessarily a new phenomenon. In old collec- tions, the recognition of significance and an object's status as a key object have had time to accumulate throughout the history of the museum. In these cases, it is easy to point out meaningful objects of collections, such as the Mesolithic soapstone object, Elk's Head of Huit- tinen in the collection of the Finnish National Museum, the mid-19th century cow leather diving suit, The Old Gentleman in the Raahe Museum or the oil painting Fighting Capercail- lies (1886) by Ferdinand von Wright from the Finnish National Gallery's collection. These artefacts possess the highest level of museum value. It is also possible to start an investigation of possible key objects and their significance by collecting existing information on collection objects, surveying current values of museum staff and visitors and enriching this knowledge by new research. This could be done by active collection work, research and discussions, as well as by interviews directed towards the public or surveying the marketing material of museums, as was done in the Key Objects of Collections survey published in 2018 (Lehto-Vahtera 2018). This survey, published by the Aboa Vetus \& Ars Nova Museum in Turku, aimed to

connect the knowledge that museums have on certain collection items and visitor experiences in order to show the power of museum objects as memory makers.

These recent writings give emphasis to the environment in which the museum context has been created and accumulated, as well as offer- ing additional building blocks for constructing museum identity. It has to be kept in mind, however, that it is not only a question of single objects, their significance or their key role as part of a museum collection. It is about the pro- cess in which one museum item has to be seen as part of a greater heritage reserve, regardless of ownership. It is important to see the collections that we have as a reserve, regardless under whose ownership they might be at any given time in history, and to see museums pointing out signi- fication in this reserve. Furthermore, it is important to learn to comprehensively evaluate and give meaning to processes:

This approach requires a comprehensive and integrated perspective on heritage, that is, an approach where all heritage sectors play a role. The traces of history and the stories are recorded by many different heritage institutions: museums, archives, libraries, and organizations in the field of built heritage and nature and land- scape protection, but also organizations con- cerned with intangible heritage (folk dance groups, etc.). Together these institutions consti- tute the memory of the place. It involves more than preservation and availability of informa- tion. It's mainly about signification (Van Men- sch and Meijer-van Mensch 2011: 93). 
It is seen through these processes that meanings and value are constructed, and muse- ums are made to matter. It is not only museums, but also the whole heritage sector that should be involved in this process. In order to participate,

Article: Promoting Value Practice in Museums Creates Impact

value discussion is needed, and the work ends up having an impact. In general, the concept of an impact factor has been chosen as a key one when studying meaningfulness in society, either from the economic point of view or a more intangible one (Conn 2010; Davies 2011; Hol- den 2006; Scott 2013; Weil 2002). What do people consider meaningful in their own envi- ronment, and why? Through active value dis- cussion museum professionals will be better equipped to respond to these questions and to any short-term fluctuations in their everyday work. With the help of these discussions, they will be better prepared to help mediate impor- tant issues in the heritage field for future deci- sion makers. In this process it is important that museum professionals understand and see their working role as mediators, and not merely as contemporary consumers. One can ultimately address this issue through the following ques- tion: To what extent has the entire museum succeeded in its work as a mediator?

One way to measure such success is to look at the impact factor of meaningful objects in society. Museum collections and the network of values embedded within them are things that not many other institutions in society possess. This reality should not be disregarded in time and place, where one's own impact is a factor. It is important to understand that there have been institutional structures showing interest towards meaningful objects, century after cen- tury. The fact that there are societies in the world that consider museum collections impor- tant is a straightforward indicator that an impact factor is indeed present. The continued care and existence of museum objects through- out the centuries is very strong evidence of this.

My article introduces the term "museologi- cal value discussion" (museologinen arvokes- kustelu) as a way to make these issues visible. To use the term "museological value discussion"

takes a comprehensive approach to collection development. With this, it is meant that the value perspective of the discussion is wider than just one object and its potential value accumula- tion. It also means seeing values accumulating century after century. This understanding does not restrict itself only to museums as institutions or their collections but leads to a wider perspec- tive and encompasses all museologically mean- ingful phenomena in society (Hudson 1993; Sola 2004; Van Mensch and Meijer-van Men- sch 2011). This aspect helps us to understand historically significant objects comprehensively, where museums as institutions are one part of the whole.

Museums and their collections do not exist in an isolated past, nor do they bear meaning only in our current society but carry meaning and understanding from the past to the present and to the future. In this process, a comprehen- sive point of view is essential because it allows us to view values from a longer lasting and wider perspective. This includes pointing out the net- work of values meaningful to museums and car- rying significance from past generations onward. In this discourse, we need museological value discussion. When museum professionals see their role as mediators, they function as important links and carry on the work of past generations. The Professor of Museology at Jyv€askyl€a University sees the situation as fol- lows:

"Professionalism related to research and preservation work of the current museum gen- eration will greatly determine what kind of past we will have in the future." (Vilkuna 2003: 10).

Museological value discussion results in a value network, which consists of selected values specific to a given museum or heritage organiza- tion. This network is created in a process, in which the organization itself determines the specific values for its identity. This network is not based only on our current idea of values or

Nina Robbins

5

CURATOR: THE MUSEUM JOURNAL 
identity, but on those that have accumulated century after century and is seen, for example, in the existence and caretaking of a collection object throughout history. It is seen in the obvi- ous key objects of our culture and the signifi- cance that these objects have accumulated. By studying these networks, specific to each museum and its identity, it is possible to gain information about the mutual values of muse- ums, in order to reach a common voice.

The need for a museological value discus- sion becomes evident when studying the field further, especially in the process of evaluating a museum's own identity. When determining any long-term decisions affecting a museum's col- lection or identity, museological value discus- sion comprehensively takes into account the entire span of everyday museum practices. However, it also addresses the need to consider both philosophical and practical approaches. For example, it functions as a bridge between philosophical issues such as good vs. bad collec- tion items and more pragmatic issues, such as the monetary-oriented values (i.e. insurance values or accounting values) of collections. It is not enough for such a discussion to be based only on philosophical grounds, monetary issues or even the public's current experiences and expectations. Any value discussion has to be museologically oriented in order to cover all sec- tors of museum work and in order to have a longer-term influence.

The 2012 survey answers, where museum personnel were given an opportunity to freely choose values that best fit their museum and its collection, clearly showed that museological value discussion does in fact take place in Fin- nish art museums. The following five values emerged from the material as the most impor-tant ones in Finnish art museums: artistic, aes- thetic, museum value, research value and value related to locality (Robbins 2016: 178). These

were also congruent with the values presented in the operational documents of Finnish art museums and can be seen as reflecting their overall collective values. These five values are an integral part of the Finnish art museum value network and can eventually be utilized to help museums clarify their focus.

These factors were also discussed in the 2018 interviews with the four museum profes- sionals, who all emphasized the need for active participation and practice. In this process, the role of professional experience in achieving any comprehensive view was seen as meaningful. Furthermore, it became clear that efforts toward bridging theory and practice will be beneficial in helping to achieve any relevant practical results regarding value discussions.

\section{SIGNS OF TACIT KNOWLEDGE WITHIN COLLECTION MANAGEMENT}

The 2012 survey showed that art museum professionals in fact have a lot of information, knowledge and knowhow regarding value assess- ments. It also showed that a lot of this informa- tion is still tacit. Tacit knowledge is often contrasted with explicit knowledge. Terms such as "gut-feeling" and "knowledge at my fingertips" are often used to describe its character (Koivu- nen, 1997; Polanyi, 1966). In this article tacit knowledge is understood as something that is difficult to transfer into writing. For example, unwritten customs and caretaking procedures in the field of collection management that are upheld but have not been officially documented. These customs may not be official or written but they are nonetheless very much rooted in everyday museum practices, and this know-how is transferred to every new museum professional coming to work in the museum.

All this is valuable capital and should not be ignored. To focus on tacit information takes the

6

Article: Promoting Value Practice in Museums Creates Impact

research into areas that are hard to quantify. Nevertheless, it is important to take such areas into consideration in the humanities. It is important to study methods with which unwrit- ten and silent information can be made visible. In addition to factual knowledge involving col- lection development, we also need to study con- ceptions, attitudes and emotions.

Traditionally, professionals in Finnish museums have attained their education from var- ious types of institutions - universities, polytech- nics and trade schools. Professionals and their educational backgrounds 
only come together to form a unified museum staff in the working envi- ronment (Hakamies 2017). This is where every- day value discussions take place and also where the practical application of values can be studied.

The 2012 survey and 2017-2018 interviews and workshops suggest that it would be benefi- cial for future museum professionals to make any value related tacit knowledge visible, be it in the area of collection management or development, long-term visions, exhibitions, financial resources or pedagogical goals. I believe it's important to bring forth this unified "opinion" and study the complexity of the social phenom- ena based on everyday working experience, make it visible and expose it to academic scrutiny.

\section{MUSEUM INTERVIEWS AND WORKSHOPS}

The first chapters of this article have given the basis as to why we need value research among museum professionals and introduced the need for museological value discussion as a comprehensive method for evaluating the impact of museum work. The results presented in this chapter are a continuation of the work already done within the subject area.

The four in-depth interviews were con- ducted during spring 2018 in order to gather information about the importance of collection

work and collection-related values in the selected museums: Collection Curator from the Tuusula Art Museum (10.1.2018); Collection Management Director from the National Gal- lery of Finland (6.2.2018); Collection Curators from the Rovaniemi Art Museum (21.2.2018) and the Helsinki City Museum (4.5.2018).

Information about the current value situa- tion within the field of collection development was collected through these two-hour inter- views by presenting the same set of questions to the interviewees. To interview four profession- als produces only a very small insight into all of the know-how imbedded in Finnish museums, but the museum types these professionals repre- sented gave the interviews a wider perspective than such a relatively small number of partici- pants would normally indicate. In total, there are 154 professionally operated museums in Finland, which have 323 separate museum loca- tions under their care. Professionally operated museums require full time museum operations, regular opening hours and at least one full-time employee who has completed studies in museol- ogy (Museotilasto 2018). The principle behind choosing these museums for the interviews was an attempt to gain current information from large museums, such as The National Gallery and The Helsinki City Museum. It was also considered important to get the opinion of a museum that has a strong local identity and a significant contemporary collection. Finally, it was meaningful to gain knowledge of collection management from a museum that houses both artworks and cultural historical material. The aspects of housing a large collection, having local significance and taking care of mixed col- lections were all seen as important, and were seen to some degree to represent professional museums in Finland overall.

The selection of the interviewees was based on experience. This need became clear from the

Nina Robbins

7

CURATOR: THE MUSEUM JOURNAL

2012 survey answers (Robbins 2016; 2017). Regarding the study at hand it was considered important that the person interviewed would have a long-term and thorough understanding of their collection content, would need to deal with value-based discussions in their everyday duties and have large collections under their care. One has to keep in mind that the museum sector in Finland is relatively modest in terms of the number of professionals and number of large collections as compared to larger European museums (Museotilasto 2018).

In addition to the museum interviews, four hands-on value workshops for students were organized in 2017 and 2018, in Helsinki and Amsterdam. Bachelor's- and master's-level stu- dents of the Museum Studies program from Helsinki University (9.11.2017 and 12.12.2018), master's-level students of the Museum Studies program from the Reinwardt Academy in Ams- terdam (10.10.2018) and bachelor's-level stu- dents of conservation from the Metropolia Polytechnic in Helsinki (30.11.2018). The information gained through these workshops functioned as a comparison to the interview material and enlarged the scope to include pre- sent and future museum 
professionals. Students from the Reinwardt Academy were the most international. In this group, there were students from the Netherlands, Brazil, India, Spain and Italy. The first group of Finnish students was still completing their studies on the bachelor's-level, whereas the second Finnish university group was master's-level students who had also gained practical experience thorough internships in museums. In the group of conservation students, study lines such as painting, paper, object, textile and furniture were represented. These groups were chosen for the workshops in order to observe any differences in experience and pre- paredness toward value discussion based on the amount of study credits.

Both the four interviews and the four value workshops were conducted, keeping the meth- ods of Grounded Theory in mind, where space is left for free contemplation, and where theoreti- cal formation can be developed as the research proceeds (Charmaz 2006; Glaser and Strauss 1999; Strauss and Corbin 1998). The proce- dures offered by Grounded Theory gave the possibility to utilize a co-operative method, where the role of experienced colleagues made rich and in-depth discussions possible. In this way the interview situation could be interpreted as a peer-research process instead of as a researcher-recipient process. The selection of collection professionals working with both art and cultural historical collections in large muse- ums, in one local museum and in one significant museum outside the metropolitan area was seen as a potential starting point for rich data. This was seen as possessing interpretive value, even though only four members of the museum pro-fession were interviewed. Furthermore, inter- views with museum professionals and free discussions at the end of each workshop with students brought up themes and issues that were not part of the original plan. The verification of collected data was done after each session and modified, if necessary, for the following inter- views and workshops. In this way the research material was enriched, and potentially tacit information had a chance to surface. All but one workshop took place after the interviews and the answers of the professionals guided themes during the student discussions. This gave the opportunity for such professionals to share their thoughts with students, thus also emphasizing the co-operative aspect. All in all, the method gave an opportunity for any common value ground to surface. To search for any common ground may seem odd in the present-day cli- mate of individualism, but indeed to find com- mon ground and consensus is something that

8

Article: Promoting Value Practice in Museums Creates Impact

might help facilitate value-based decision mak- ing in the area of collection care.

All the interviewees were museum profes- sionals in charge of collection management who gave their permission to publish the interview material. The interviews were conducted by pre- senting the same set of questions to each inter- viewee and making notes of their answers. At the end of the interviews, all the notes were read and accepted by the interviewees. In general, five focal points for further development were obtained from this material: 1) to clarify the ter- minology used when engaging in value discus- sions, 2) to reach consensus on value goals, 3) to be prepared for and actually practice value talk, 4) to open the discussion on the acceptable level of collection care and 5) to recognize the various focal points that different museums have.

One of the issues brought up in the inter- views was the question of terminology, espe- cially how the term "national" is entering the forum of critical debate. Especially in the field of collection care the role of Finland's national collection (kansalliskokoelma) has been dis- cussed, as was stated by the Collection Manage- ment Director from the National Gallery. The role of the terms "collective" and "national" was discussed, i.e. what is meant by these terms in our current culture? Is there a need for a collec- tive memory in the future, and if so, why? It was also discussed that the history of the modern museum and national awakening go hand in hand in Finland. Furthermore, one has to keep in mind that even if the sense of collectiveness should diminish in the future, museum collec- tions and their objects will still remain. This is why it was further indicated by the Collection Curator from the Tuusula Art Museum "that any value processes in museums should have a longer lifespan than one museum career". She also noted that the long-term requirement of collection work does not correspond well to the

current division of city functions into various service organizations, organizations that aim to provide services to current citizens, thus operat- ing with a much shorter timeline and perspec- tive. This aspect should definitely be discussed and further developed so that the organizational structure would recognize the need for longer- term planning in the museum sector. These needs should be recorded in the official museum documents and made visible to future genera- tions to allow younger museum professionals see the accumulation of knowledge. 
Furthermore, it was discussed that museum professionals have to be active, learn and main- tain vigilance regarding value discussion, and they have to learn to stay prepared, since "im- pulses for value discussion emerge from every- day situations which may need fast responses", as was described by the Tuusula Art Museum Curator. On a practical level, this might mean a situation where a public artwork is removed from its original space and museum profession- als are forced to make quick decisions as to the replacement of the artwork. The preparedness for fast responses has to be there, and this can only be reached by value practice. These con- cerns were also present in the 2012 survey answers, as can be seen in the quotation below:

One of the difficulties is that a work of art in a collection will remain art, even if we do not possess the needed tools for a definition of art. Even the relevant legislation does not give us any accurate definition as to when an artwork threshold is reached, not to mention all the needed quality requirements of art. From a copyright point of view, bad art will also always remain art. The difficulties appear when one has to determine between good and bad art. In the process of value assessment, one has to acknowl- edge one's own subjectivity and historicity (Rob- bins 2016: 176).

Nina Robbins

9

CURATOR: THE MUSEUM JOURNAL

These examples also show that value discussion may include subjects from small to large and from abstract to very concrete. Furthermore, the 2012 survey showed that museum professionals are often unaware that these everyday discussions are, in fact, value- based in nature. For example, value discus- sions often appear in various day-to-day sit- uations, such as prioritizing decisions regarding collection work, the in-situ selec- tion of guiding styles or emphasizing various research goals. They also become visible in larger issues, e.g. when discussing the role of the museum as part of a city's strategic structure. For local museums in particular, value work done in the sector of audience engagement plays a large role and is seen as a method of engaging and empowering dif- ferent audiences. This became clear form the answers stated by the Rovaniemi Art Museum Curator in the 2018 interviews: "There could be various values simultane- ously present within the same institutional structure". Eventually the importance of locality and variety of focal points was acknowledged. These issues were important for the Rovaniemi Art Museum. This means that there are local museums that operate in locations that also house other functions, such as learning facilities, orchestras or eve- ning activities. In these cases, any value discussion has to be partially aligned with these other functions. Furthermore, the issue of locality may cause values to be seen based on latitude, taking cultural similarities into account, rather than similarities within national borders, as is the case with the Rovaniemi Art Museum and their co-opera- tive projects with Sami communities.

One main issue in the field of collection management was a discussion about the accept- able level of collection care. This was especially

a concern for large collections such as the Fin- nish National Gallery. Museums often face a situation where the costs to upkeep collection facilities increase, while funding for long-term preservation remains the same. This leads to a question of prioritizing and eventually to a dis- cussion of the acceptable level of collection care, if and when the desired or ideal situation cannot actually be reached. In order to be able to deter- mine the acceptable level, one needs to reach an overall picture of the pros and cons and ask questions such as the following: "What is the amount of our care debt?" as was presented by the Collection Manager from the National Gal- lery, or "How many objects are enough?" as the Helsinki City Museum Curator asked. To answer these questions, I believe that we need museological value discussion to function as an internal tool for museum professionals. Only after this work can information regarding col- lection identity be passed on to other stakehold- ers and audiences. No doubt, it is possible to include participants from various fields of soci- ety in these discussions, as was shown by the previous examples of analyzing significance. Nevertheless, opinions of the interviewees showed that in order to successfully conduct such co-operation, professional experience is required.

It was commented on by all of the intervie- wees that collection-oriented value discussion needs practice in order to accumulate its vocab- ulary. It was seen as important to voice one's own everyday work and make its tacit character visible. This was seen as one method of helping the accumulation of value vocabulary. It was also seen that "the creation of an argumentation portfolio of this kind would bring depth to situ- ations where broad structural conditions such as local politics play a role. It would also diminish the possibility of any wrong signals", as the Tuusula Art Museum Curator indicated. 
Finally, she pointed that this kind of active and on-going value practice would lead to deeper outcomes than would value remarks by them- selves, which are made more on the basis on visi- tor surveys or financial resources.

The interviews provided information to further develop material for students and pro- fessionals. As a result, educational days for museum professionals regarding collection care values are being planned and carried out. Fur- thermore, workshops for students regarding condition of collections were conducted for stu- dents from various heritage study programs. The first workshop test-run for bachelor's-level students took place in November 2017. This was to test the students' preparedness to partici- pate in value related discussions. Similar work- shops have been conducted by various institutions in order to provide insight into the material value of museum objects (Simil€a and Eastop 2017). The 2017 test showed that stu- dents are eager to state their opinions and learn more about the practical application of value discussion but need more guidance in accumulating the value discussion vocabulary. To develop these workshops, both for professionals and students, is seen as a valuable hands-on tool that will eventually have the potential to increase museum impact.

Eventually, the 2018 workshops for stu- dents were conducted in several steps. Students discussed values in groups, using cards that rep- resented six levels of damage (good condition, information missing, wrinkles, tears, stains and burn marks). After a discussion, they divided these cards into four value classes (main collec- tion, usage collection, evaluation collection and disposal collection). Time was allowed for a thorough discussion, after which each group presented their evaluation. Finally, all informa- tion was displayed together, and students formulated statements as to why each card

belonged to a specific value class. At the end of the session, the class discussed the differences found in each group's decision and learned to assert and justify their own value judgments.

There were some common features that all of the groups shared. One of these was the strong view that the selection into a specific value class always needs a knowledge of context in order to be solid. This was seen as very impor- tant and implies that condition can never be the mere starting point for drastic collections decisions. Furthermore, all value statements and discussions from the four sessions raised three main issues. (1) The context and background of the object at hand both need to be researched and known before any final decisions are made. (2) Any damage to museum objects might become a source of information or subsequently the genesis for storytelling. (3) Evaluation takes time and experience.

It was easy for all of the students and groups to find the objects that belonged to the first and last value classes, but decisions regarding the middle value classes (usage collection and evalu- ation collection) reached less consensus. The master's-level university students indicated that the context and the group of representatives have to be known, i.e. if objects in poor condi- tion are the only representatives of their group, they might nonetheless be valuable for the col- lection. The conservation students were under- standably more familiar with the issue of condition, and their selections seemed to be more coherent. The bachelor's-level students found the exercise important in developing their skills in articulating value. Students that were further along in their studies also utilized a wider perspective, asking, for example, if the result would be different if we had other focuses than just condition in mind? This wider per- spective could include a multitude of situations where different types of collections, acquisitions

Nina Robbins

11

CURATOR: THE MUSEUM JOURNAL

or disposals were our focal points. Again, aspects of allowing time, having experience, knowing the specific context and reaching con- sensus were among the main issues discussed. 
From these workshops, one could clearly see that the condition of the museum object is not by itself enough to decide its status; more information is needed. Students' statements such as "damages are interesting" or "damages tell a story" further support this. Conducting the workshops for four different groups of stu- dents in three different educational institutions clearly showed that this kind of hands-on prac- tice is needed and will lead to a more profound learning experience. Value workshops suggest one path to make tacit knowledge regarding col- lection care more visible and also available for scrutiny. Furthermore, they will equip students with a more extensive vocabulary for expressing museological values. It will be possible to take this demand into account in the planning of future Museum Studies courses of the Helsinki University, since the teaching methods for Museum Studies were updated in 2017 and more collaborative and hands-on methods were introduced (Thomas et al., 2018). In the new curriculum museum professionals are included in sharing their knowledge with students, and all courses are planned so that students will take part in more actual hands-on museum work during their studies. This way, the information flow will remain up-to-date at all times and stu- dents will be better equipped for value-related discussions when starting their careers.

\section{TO HAVE VALUES AT OUR FINGERTIPS}

The 2018 interviews and student work- shops gave a good starting point for further development of value practices for museums professionals. They also were a good update to the 2012 survey. The message seems clear.

Practice in the area of museological value dis- cussion is needed and an accumulating value portfolio would be useful. Collection work has to be understood as a long-term endeavor that has somewhat divergent goals than those most valued by the current service-oriented city struc- tures. Discussion about terminology is needed, and the tacit side of collection work needs to become more visible. Local issues have to become part of value discussion, and geographi- cal differences in identity have to be better understood. These factors were brought up repeatedly.

Even though the museological value dis- cussion is mainly intended to be used as an internal tool for museum professionals, it will eventually have consequences that would bene- fit the public as well. The transparency of museum collection work could result in writ- ings, publications and exhibition texts that open up behind-thescenes actions and motifs to the general public, for example, by making the motifs of any particular exhibition process visi- ble to the public by including these motifs as part of exhibition material.

There is an often-used expression, "to have something at your fingertips" in the field of con- servation. This means that you have profession- ally reached a point where the knowledge that you have read and learned has been transferred to your fingertips, so to speak, becoming part of the almost automatic gut-feeling experience that guides your sharp scalpel. This process "to have values at our fingertips" will be the ultimate goal in the field of museological value discussion for museum professionals at large. END

\section{REFERENCES}

Anderson, G. (ed.). 2004. Reinventing the Museum - Historical and Contemporary Perspectives on the Paradigm Shift. Lanham, MD: Altamira Press.

Article: Promoting Value Practice in Museums Creates Impact

Appelbaum, B. 2007. Conservation Treatment Methodology. Oxford, UK: Butterworth- Heinemann.

Artefacta. 2016. Konkreettinen esinetutkimus harvinaista. Accessed December 20, 2018. Retrieved from http://www.artefacta.fi/uutiset/ konkreettinen_esinetutkimus_harvinaista.552. news

Cultural Heritage Agency. 2014. Assessing Museum Collections - Collection Valuation in Six Steps. Amersfoort, Netherlands: Cultural Heritage Agency. Accessed March 2, 2019. Retrieved fromhttp://www.cultureelerfgoed.nl/sites/defa ult/files/publications/assessing-museum-collec tions.pdf 
Conn, S. 2010. Do Museums Still Need Objects? Philadelphia, PA: University of Pennsylvania Press.

Danto, A. 1964. “The Artworld.” The Journal of Philosophy 61(19): 571-84.

Davies, P. (ed.). 2011. Museums and the Disposal Debate. A Collection of Essays. Edinburgh: Museums Etc.

Dickie, G. 1971. Aesthetics: An Introduction. Indianapolis, IN: Pegasus.

1974. Art and Aesthetics: An Institutional Analysis. New York, NY: Cornell University Press.

2001. Art and Value. Oxford, UK: Blackwell. Ehdotus museopoliittiseksi ohjelmaksi. 2017.

Opetus- ja kulttuuriministeri€on julkaisuja 9/ 2017. Accessed March 2, 2019. Retrieved from http://urn.fi/URN:ISBN:978952-263-455-9

Glaser, B., G. Strauss, and L. Anselm. 1999 (1967, 1971). The Discovery of Grounded Theory: Strategies for Qualitative Research. New York, NY: Aldine de Gruyter.

Haapala, A. 2010. "Arvot, arvostukset ja taidekokoelmien kartuttaminen”. In Kokoelmalla on tekij€ans€a, edited by T. Jyrkkio€, and E. Liukkonen 65-79. Valtion taidemuseo KEHYS. Helsinki: Valtion taidemuseo.

Hakamies, I. 2017. “Practice Makes 'Museum People'." Museum and Society 15(2): 142-52.

Holden, J. 2006. Cultural Value and the Crisis of Legitimacy. London, UK: DEMOS. Accessed March 2, 2019. Retrieved from https://www.de mos.co.uk/files/Culturalvalueweb.pdf

Hudson, K. 1993. “The Great European Museum.” Nordisk Museologi 0(2): 51-60.

H€ayh€a, H., S. Jantunen, and L. Paaskoski. 2015. Merkitysanalyysimenetelm€a. Helsinki: Suomen Museoliitto. Accessed March 2, 2019. Retrieved from https://www.museoliitto.fi/doc/Merkitysa nalyysimenetelma1.pdf

ICOM Strategic Plan 2016-2022. 2018. Accessed July 8, 2019. Retrieved from https://ic om.museum/wpcontent/uploads/2018/06/ ICOM_STRATEGIC_PLAN_2016-2022_ENG.pdf

Knell S. (ed.). 2004. Museums and the Future of Collecting. Burlington: Ashgate.

Koivunen, H. 1997. Hiljainen tieto. Helsinki: Otava. Lehto-Vahtera, J. (ed.). 2018. Kokoelmien avaimet - Museokokoelmien tunnisteobjekteja. Turku: Aboa

Vetus \& Ars Nova.

Museovirasto. 2018. Museotilasto. Accessed

November 17, 2019. Retrieved from https:// www.museotilasto.fi/tiedostot/museovirasto/f iles/Tilastokortti\%201_2017.pdf

The Museums Association. 2012. Museums 2020 Discussion Paper. Accessed March 2, 2019. Retrieved from http://www.museumsassoc iation.org/museums2020

Piekkola, H., O. Suojanen, and A. Vaino. 2013. Museoiden taloudellinen vaikuttavuus. Vaasa: Vaasan yliopisto Levoninstituutti.

Polanyi, M. 1966. The Tacit Dimension. London: Routledge \& Kegan Paul.

Porter, M. E., and M. R. Kramer. 2011. Creating Shared Value. Harvard Business Review. Accessed March 2, 2019. Retrieved from https:// hbr.org/2011/01/the-big-idea-creating-shared-value

Robbins, N. 2016. Poisto museokokoelmasta - Museologinen arvokeskustelu kokoelmanhallinnanm€a€aritt€aj€an€a. Jyv€askyl€a studies in humanities 283. Jyv€askyl€a: Jyv€askyl€an yliopisto. Accessed September 15, 2017. Retrieved from http://urn.fi/URN:ISBN:978- 951-39-6581-5 
CURATOR: THE MUSEUM JOURNAL

- - 2017. "MuseumCollectionDisposal-The Role of Museological Value Discussion in Collection Management.” The Museums Review 2(1). Accessed December 20, 2018. Retrieved from http://articles.themuseumreview.org/ vol2no1robbins

Russell, R., and K. Winkworth. 2009. Significance 2.0: A Guide to Assessing the Significance of Collections. Heritage Publications. Accessed March 2, 2019. Retrieved from www.environme nt.gov.au/heritage/publications/significance20/part-1/index.html

Scott, C. 2008. “Using Values to Position and Promote Museums.” International Journal of Arts Management 11(1), 28-41.

——— (ed.). 2013. Museums and Public Value. Burlington: Ashgate.

Simil€a, K., and D. Eastop. 2017. Workshop: The Relationship of Material Change and Perceived 'Value' of Objects. In: To Recycle, mend or discard? Seminar in Jyv€askyl€a 20.-21.4.2017. Accessed March 2, 2019. Retrieved from http:// kiertoonkorjaukseenvaipoistoon.blogspot.com

Simon, N. 2010. The Participatory Museum. Santa Cruz, CA: Museum 2.0.

Sola, T. 2004. "Redifining Collecting. Teoksessa.” In Museums and the Future of Collecting, edited by S. J. Knell (toim.), 25060. Burlington: Ashgate.

Strauss, A., and J. Corbin. 1998. Basics of Qualitative Research - Techniques and Procedures for Developing Grounded Theory. London, UK: Sage.

Thomas, S., A. Wessman, and E. Heikkil€a. 2018. "Redesigning the Museum Studies Programme at the University of Helsinki: Towards Collaborative Teaching and Learning.” Journal of Museum Management and Curatorship 33(4): 344-64.

Van Mensch, P., L. Meijer-van Mensch. 2011. New Trends in Museology. Celje: Museum of Recent History Celje.

Vilkuna,J.2003.T€aytetyntiikerin€a€arell€a.Museologia, mit€a se on?, 5-10. Accessed March 2, 2019. Retrieved from http://www.tieteessatapahtuu.fi/ 037/vilkuna.pdf

Weil, S. 2002. Making Museums Matter. Washington: Smithsonian Books.

Wollheim, R. 1980. Art and Its Objects. Cambridge: Cambridge University Press.

14

Article: Promoting Value Practice in Museums Creates Impact

\section{Multi-language Abstract}

The contents of this page will be used as part of the multi-language abstract as part of the html version. It will not be published as part of main article in the print or PDF version

T€am€a artikkeli k€asittelee suomalaisten museoiden kokoelmanhallintaan liittyv€a€a arvokeskustelua, ja esittelee museoammattilaisten haastattelujen ja museoalan opiskelijoille suunnattujen ty€opajojen kautta saatua tietoa. Artikkelin fokuksena on tuottaa sek€a museoammattilaisille ett€a museoalan opiskelijoille k€ayt€ann€on ty€okaluja ottaa aktiivisesti osaa arvokeskusteluihin. T€am€an ty€on tuloksena yhteiskunnan eri sektoreiden on mahdollista tunnistaa museologisen arvokeskustelun t€arkeys, ja nostaa erityisesti voittoa tavoittelemattomien arvojen merkityst€a. Tarkoituksena on l€oyt€a€a hyvi€a k€ayt€ann€on toimintamalleja ja vahvistaa museoammatti- laisten kyvykkyyksi€a tehd€a kest€av€a€a kulttuurity€ot€a. T€all€a toiminnalla on pitk€akestoista vaikuttavuutta. 